\title{
Should laboratory assay quality be described in study publications and clinical guidelines? A focus on testosterone assay performance
}

\author{
Sudarshan Ramachandran, Mark Livingston, \\ Geoffrey Hackett, Richard C. Strange
}

Over the past 25 years evidence based medicine has been increasingly used by healthcare professionals in the United Kingdom in the development of guidelines. According to Sackett et al in 1996, a "conscientious, explicit, and judicious use of current best evidence in making decisions about the care of individual patients" integrates clinical expertise with evidence from systematic research [1]. More recently Djulbegovic and Guyatt in 2017 suggested that evidence based medicine has ensured clinical medicine adopted trustworthy guidelines based on science and evolving methodology [2]. It is our view that the clinical laboratory has a major role in ensuring that recommendations based on biochemical measurements are robust.

To illustrate this point we highlight laboratory issues that support the British Society for Sexual Medicine (BSSM) guidelines on adult onset testosterone deficiency

Sudarshan Ramachandran ${ }^{1,2,3}$, Mark Livingston ${ }^{4}$, Geoffrey Hackett $^{5}$, Richard C. Strange ${ }^{6}$

Affiliations: ${ }^{1}$ Department of Clinical Biochemistry, University Hospitals of North Midlands/Facultyof Health Sciences, Staffordshire University, Staffordshire; ${ }^{2}$ College of Engineering, Design \& Physical Sciences, Brunel University London, Uxbridge; United Kingdom; ${ }^{3}$ Department of Clinical Biochemistry, University Hospitals Birmingham NHS Foundation Trust, Rectory Road, Sutton Coldfield, West Midlands, B75 7RR; ${ }^{4}$ Department of Blood Sciences, Black Country Pathology Services, Walsall Manor Hospital, Walsall, WS2 9PS; ${ }^{5}$ School of Health and Life Sciences, Aston University, Birmingham, England, United Kingdom; ${ }^{6}$ Institutes for Science and Technology in Medicine, Keele University, Staffordshire, England, United Kingdom.

Corresponding Author: Sudarshan Ramachandran, Department of Clinical Biochemistry, University Hospitals Birmingham NHS Foundation Trust, Good Hope Hospital, Rectory Road, Sutton Coldfield, West Midlands B75 7RR, United Kingdom; Email: sud.ramachandran@heartofengland.nhs. uk

Received: 04 April 2019

Published: 07 May 2019
[3]. The guidelines state that men with total testosterone $<8 \mathrm{nmol} / \mathrm{l}(230.74 \mathrm{ng} / \mathrm{dl})$ or free testosterone $<0.180$ $\mathrm{nmol} / \mathrm{l}(5.19 \mathrm{ng} / \mathrm{dl})$ usually require testosterone therapy (TTh) while men with total testosterone levels between 8-12 nmol/l (230.74-346.10 $\mathrm{ng} / \mathrm{dl})$ may require TTh depending on the presence of symptoms associated with testosterone deficiency.

The studies included in the BSSM guidelines using testosterone levels used to characterise or determine the study cohort to identify men who may benefit from TTh are shown in Table 1 [4-12]. Importantly, only two of the nine studies in Table 1 described the specific assays used and none provided information on assay performance $[7,8]$. As the BSSM and other guidelines have used specific testosterone concentrations to identify men who should be considered for TTh, standardisation of the assays used to measure concentrations of this analyte together with data on assay accuracy and precision are essential. Further, since two of the studies stratified the cohorts using reference ranges $[4,9]$ it is also important that universally accepted reference ranges are used in comparisons of patient cohorts. Such ranges may of course vary between populations.

It is hoped that the programs such as that of the Centers for Disease Control and Prevention (CDC) (https://www.cdc.gov/labstandards/pdf/hs/HoSt Brochure.pdf - accessed 04/04/2019) and the availability of reference materials will help assay manufacturers and laboratories to standardise testosterone methods. This is essential if action thresholds are suggested by guidelines and protocols. Interestingly, Cao et al in 2017 distributed four samples ( 2 males and 2 females) to 142 accredited laboratories (testosterone concentrations: $15.5 \mathrm{ng} / \mathrm{dl}$ (0.54 nmol/l), $30 \mathrm{ng} / \mathrm{dl}(1.04 \mathrm{nmol} / \mathrm{l}), 402 \mathrm{ng} / \mathrm{dl}$ (13.94 $\mathrm{nmol} / \mathrm{l})$ and $498 \mathrm{ng} / \mathrm{dl}(17.27 \mathrm{nmol} / \mathrm{l})$ and studied assay performance compared to target values using reference measurement procedures operated by the CDC reference laboratory [13]. It was observed that considerable bias existed for all the distributed samples $-17.8 \%$ to $73.1 \%$, $3.1 \%$ to $21.3 \%,-24.8 \%$ to $8.6 \%$, and $-22.1 \%$ to $6.8 \%$ for the four samples respectively. Similarly wide variation of assay performance are reported by Birmingham Quality on behalf of the National External Quality Assessment 


\section{EDORIUM Journals}

\section{www.edoriumjournalofbiochemistry.com}

Table 1: Studies included in the BSSM guidelines using testosterone levels used to identify men who may benefit from testosterone therapy

\begin{tabular}{|c|c|c|c|}
\hline Study & $\begin{array}{l}\text { Testosterone } \\
\text { assay }\end{array}$ & $\begin{array}{l}\text { Number } \\
\text { of } \\
\text { Centres }\end{array}$ & $\begin{array}{l}\text { Reporting } \\
\text { of assay } \\
\text { performance } \\
\text { (Y/N) }\end{array}$ \\
\hline $\begin{array}{l}\text { Anderson et } \\
\text { al. [4] }\end{array}$ & $\begin{array}{l}\text { immunoassay, } \\
\text { multiple } \\
\text { methods }\end{array}$ & multiple & $\begin{array}{l}\mathrm{N} \text { (stratification } \\
\text { based on } \\
\text { laboratory } \\
\text { reference } \\
\text { ranges) }\end{array}$ \\
\hline $\begin{array}{l}\text { Basaria et al. } \\
\text { [5] }\end{array}$ & not specified & single & $\mathrm{N}$ \\
\hline $\begin{array}{l}\text { Cheetham et } \\
\text { al. [6] }\end{array}$ & not specified & multiple & $\mathrm{N}$ \\
\hline $\begin{array}{l}\text { Hackett et al. } \\
\text { [7] }\end{array}$ & $\begin{array}{l}\text { Roche } \\
\text { Immunoassay }\end{array}$ & single & $\mathrm{N}$ \\
\hline $\begin{array}{l}\text { Muraleedaran } \\
\text { et al. [8] }\end{array}$ & $\begin{array}{l}\text { Bayer Advia } \\
\text { Centaur \& DRG } \\
\text { immunoassay }\end{array}$ & two & $\mathrm{N}$ \\
\hline $\begin{array}{l}\text { Sharma et al. } \\
\text { [9] }\end{array}$ & $\begin{array}{l}\text { multiple } \\
\text { methods, not } \\
\text { specified }\end{array}$ & multiple & $\begin{array}{l}\mathrm{N} \text { (stratification } \\
\text { based on } \\
\text { laboratory } \\
\text { reference } \\
\text { ranges) }\end{array}$ \\
\hline $\begin{array}{l}\text { Shores et al. } \\
{[10]}\end{array}$ & immunoassay & multiple & $\mathrm{N}$ \\
\hline $\begin{array}{l}\text { Traish et al. } \\
{[11]}\end{array}$ & not specified & single & $\mathrm{N}$ \\
\hline $\begin{array}{l}\text { Vigen et al. } \\
\text { [12] }\end{array}$ & not specified & single & $\mathrm{N}$ \\
\hline
\end{tabular}

BSSM: British Society for Sexual Medicine

Service (NEQAS) on steroid hormones (https:// birminghamquality.org.uk/assets/doc/eqa/ster-453.pdf - accessed 03/04/2019) having distributed samples to over 200 laboratories in June 2018. The following method specific mean values were seen for male testosterone.

Sample A: All methods trimmed mean $=26.8 \mathrm{nmol} / 1$ (772.3 ng/dl), Abbott Architect $=29.9 \mathrm{nmol} / \mathrm{l}(861.7 \mathrm{ng} /$ dl), Beckman Access = $21.7 \mathrm{nmol} / \mathrm{l}(625.4 \mathrm{ng} / \mathrm{dl})$, Roche Cobas $/$ Modular $=27.7 \mathrm{nmol} / \mathrm{l}(798.3 \mathrm{ng} / \mathrm{dl})$, Siemens ADVIA Centaur $=25.0 \mathrm{nmol} / \mathrm{l}(720.5 \mathrm{ng} / \mathrm{dl})$, Siemens Immulite $2000 / 25000=23.0 \mathrm{nmol} / \mathrm{l}(662.8 \mathrm{ng} / \mathrm{dl})$ and Tandem Mass Spectrometry $=26.1 \mathrm{nmol} / \mathrm{l}(752.2 \mathrm{ng} / \mathrm{dl})$.

Sample B: All methods trimmed mean $=19.8 \mathrm{nmol} / \mathrm{l}$ $(570.6 \mathrm{ng} / \mathrm{dl})$, Abbott Architect $=21.5 \mathrm{nmol} / \mathrm{l}(619.6 \mathrm{ng} /$ dl), Beckman Access = $17.3 \mathrm{nmol} / \mathrm{l}(498.6 \mathrm{ng} / \mathrm{dl})$, Roche Cobas $/$ Modular $=19.8 \mathrm{nmol} / \mathrm{l}(570.6 \mathrm{ng} / \mathrm{dl})$, Siemens ADVIA Centaur $=18.1 \mathrm{nmol} / \mathrm{l}(521.6 \mathrm{ng} / \mathrm{dl})$, Siemens Immulite $2000 / 25000=36.8 \mathrm{nmol} / \mathrm{l}(1060.5 \mathrm{ng} / \mathrm{dl})$ and Tandem Mass Spectrometry = $19.5 \mathrm{nmol} / \mathrm{l}(562.0 \mathrm{ng} / \mathrm{dl})$.

Sample C: All methods trimmed mean $=18.9 \mathrm{nmol} / 1$ $(544.7 \mathrm{ng} / \mathrm{dl})$, Abbott Architect $=20.9 \mathrm{nmol} / \mathrm{l}(602.3 \mathrm{ng} /$ dl), Beckman Access = $15.6 \mathrm{nmol} / \mathrm{l}(449.6 \mathrm{ng} / \mathrm{dl})$, Roche Cobas $/$ Modular $=19.2 \mathrm{nmol} / \mathrm{l}(553.3 \mathrm{ng} / \mathrm{dl})$, Siemens
ADVIA Centaur $=18.2 \mathrm{nmol} / \mathrm{l}(524.5 \mathrm{ng} / \mathrm{dl})$, Siemens Immulite $2000 / 25000=14.7 \mathrm{nmol} / \mathrm{l}(423.6 \mathrm{ng} / \mathrm{dl})$ and Tandem Mass Spectrometry = $18.7 \mathrm{nmol} / \mathrm{l}(538.9 \mathrm{ng} / \mathrm{dl})$.

From this NEQAS report, only the medians / interquartile ranges for the Accuracy (A) score for the mass spectrometry and Roche Cobas assays appear to be within target. For the results given for the Beckman Access / Dxi, the bias on one specimen reported was $-40.8 \%$ (from the target), and between-laboratory agreement for the same method gave coefficients of variation at levels under $10 \mathrm{nmol} / \mathrm{L}(288.2 \mathrm{ng} / \mathrm{dl})$ of $>25 \%$.

It is clear that considerable variation exists in testosterone assay performance and that publications often contain little information of assay performance which is essential in the interpretation of data from studies. Hence, we recommend the following measures to provide better healthcare with greater consistency:

- Assay performance of local laboratory methods is made available to clinicians and bodies drawing up guidelines and protocols.

- Data from quality assurance distribution are made available to bodies drawing up guidelines and protocols.

- Laboratory personal and representatives from quality assurance schemes play a part in guideline forming committees.

- Harmonisation of laboratory function regarding reference ranges and advice provided to clinicians is audited. It must be ensured that pre-analytical requirements and the advice provided by the laboratory are based on current evidence.

- Greater detail of types of assays and performance is included in publications.

- $\quad$ Pressure should be applied to all manufacturers to use international reference preparations (e.g. CDC) to better standardise the measurement of testosterone concentration to reduce analytical variation, analogous to the International Federation of Clinical Chemistry's standardisation of haemoglobin A1c.

Keywords: Adult onset testosterone deficiency, Clinical guidelines, Laboratory performance, Testosterone therapy, Testosterone assays

\section{How to cite this article}

Ramachandran S, Livingston M, Hackett G, Strange RC. Should laboratory assay quality be described in study publications and clinical guidelines? A focus on testosterone assay performance. Edorium J Biochem 2019;3:100007B01SR2019.

\section{Article ID: 100007B01SR2019}




\section{$* * * * * * * * *$}

\section{REFERENCES}

1. Sackett DL, Rosenberg WM, Gray JA, Haynes RB, Richardson WA. Evidence based medicine: What it is and what it isn't. BMJ 1996;312(7023):71-2.

2. Djulbegovic B, Guyatt GH. Progress in evidencebased medicine: A quarter century on. Lancet 2017;390(10092):415-23.

3. Hackett G, Kirby M, Edwards D, et al. British society for sexual medicine guidelines on adult testosterone deficiency, with statements for UK practice. J Sex Med 2017;14(12):1504-23.

4. Anderson JL, May HT, Lappé DL, et al. Impact of testosterone replacement therapy on myocardial infarction, stroke, and death in men with low testosterone concentrations in an integrated health care system. Am J Cardiol 2016;117(5):794-9.

5. Basaria S, Coviello AD, Travison TG, et al. Adverse events associated with testosterone administration. $\mathrm{N}$ Engl J Med 2010;363(2):109-22.

6. Cheetham CT, An J, Jacobsen SJ, et al. Association of testosterone replacement with cardiovascular outcomes among men with androgen deficiency. JAMA Intern Med 2017;177(4):491-9.

7. Hackett G, Heald AH, Sinclair A, Jones PW, Strange RC, Ramachandran S. Serum testosterone, testosterone replacement therapy and all-cause mortality in men with type 2 diabetes: Retrospective consideration of the impact of PDE5 inhibitors and statins. Int J Clin Pract 2016;70(3):24-53.

8. Muraleedaran V, Marsh H, Kapoor D, Channer KS, Jones TH. Testosterone deficiency is associated with increased risk of mortality and testosterone replacement improves survival in men with type 2 diabetes. Eur J Endocrinol 2013;169(6):725-33.

9. Sharma R, Oni OA, Gupta K, et al. Normalization of testosterone level is associated with reduced incidence of myocardial infarction and mortality in men. Eur Heart J 2015;36(40):2706-15.

10. Shores MM, Smith NL, Forsberg CW, Anawalt $\mathrm{BD}$, Matsumoto AM. Testosterone treatment and mortality in men with low testosterone levels. J Clin Endocrinol Metab 2012;97(6):2050-8.

11. Traish AM, Haider A, Haider KS, Doros G, Saad F. Long-term testosterone therapy improves cardiometabolic function and reduces risk of cardiovascular disease in men with hypogonadism: A real-life observational registry study setting comparing treated and untreated (control) groups. J Cardiovasc Pharmacol Ther 2017;22(5):414-33.

12. Vigen R, O'Donnell CI, Barón AE et al. Association of testosterone therapy with mortality, myocardial infarction, and stroke in men with low testosterone levels. JAMA 2013;310(17):1829-36.

13. Cao ZT, Botelho JC, Rej R, Vesper H. Accuracy-based proficiency testing for testosterone measurements with immunoassays and liquid chromatography-mass spectrometry. Clin Chim Acta 2017;469:31-6.

\section{Author Contributions}

Sudarshan Ramachandran - Conception of the work, Design of the work, Acquisition of data, Analysis of data, Interpretation of data, Drafting the work, Revising the work critically for important intellectual content, Final approval of the version to be published, Agree to be accountable for all aspects of the work in ensuring that questions related to the accuracy or integrity of any part of the work are appropriately investigated and resolved

Mark Livingston - Design of the work, Acquisition of data, Analysis of data, Interpretation of data, Drafting the work, Revising the work critically for important intellectual content, Final approval of the version to be published, Agree to be accountable for all aspects of the work in ensuring that questions related to the accuracy or integrity of any part of the work are appropriately investigated and resolved

Geoffrey Hackett - Design of the work, Drafting the work, Revising the work critically for important intellectual content, Final approval of the version to be published, Agree to be accountable for all aspects of the work in ensuring that questions related to the accuracy or integrity of any part of the work are appropriately investigated and resolved

Richard C. Strange - Conception of the work, Design of the work, Interpretation of data, Drafting the work, Revising the work critically for important intellectual content, Final approval of the version to be published, Agree to be accountable for all aspects of the work in ensuring that questions related to the accuracy or integrity of any part of the work are appropriately investigated and resolved

\section{Guarantor of Submission}

The corresponding author is the guarantor of submission.

\section{Source of Support}

None.

\section{Conflict of Interest}

Authors declare no conflict of interest.

\section{Data Availability}

All relevant data are within the paper and its Supporting Information files.

\section{Copyright}

(C) 2019 Sudarshan Ramachandran et al. This article is distributed under the terms of Creative Commons Attribution License which permits unrestricted use, distribution and reproduction in any medium provided the original author(s) and original publisher are properly credited. Please see the copyright policy on the journal website for more information. 
Access full text article on other devices

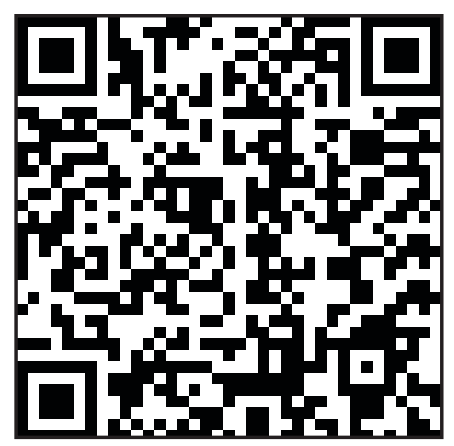

Access PDF of article on other devices

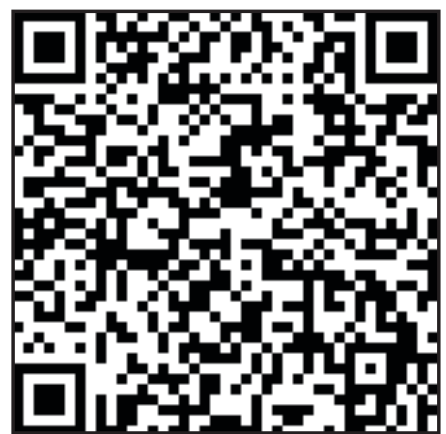




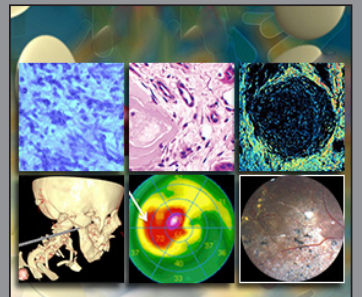

INTERNATIONAL JOURNAL OF CASE REPORTS AND IMAGES
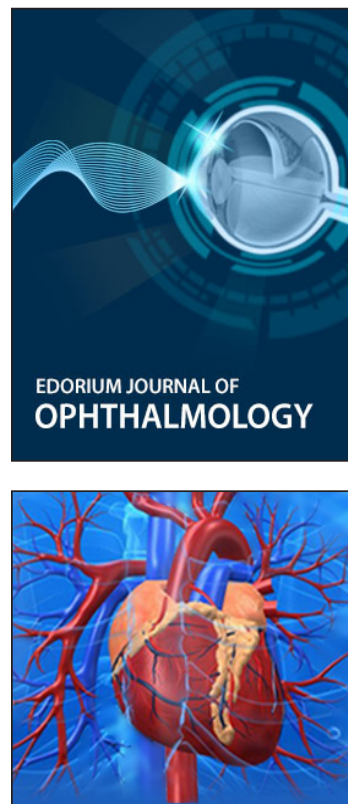

EDORIUM JOURNAL OF

CARDIOTHORACIC AND

VASCULAR SURGERY
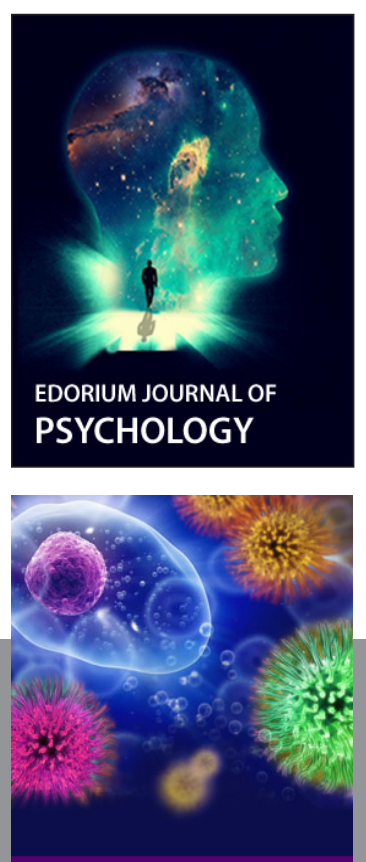

JOURNAL OF CASE REPORTS AND IMAGES IN INFECTIOUS DISEASES
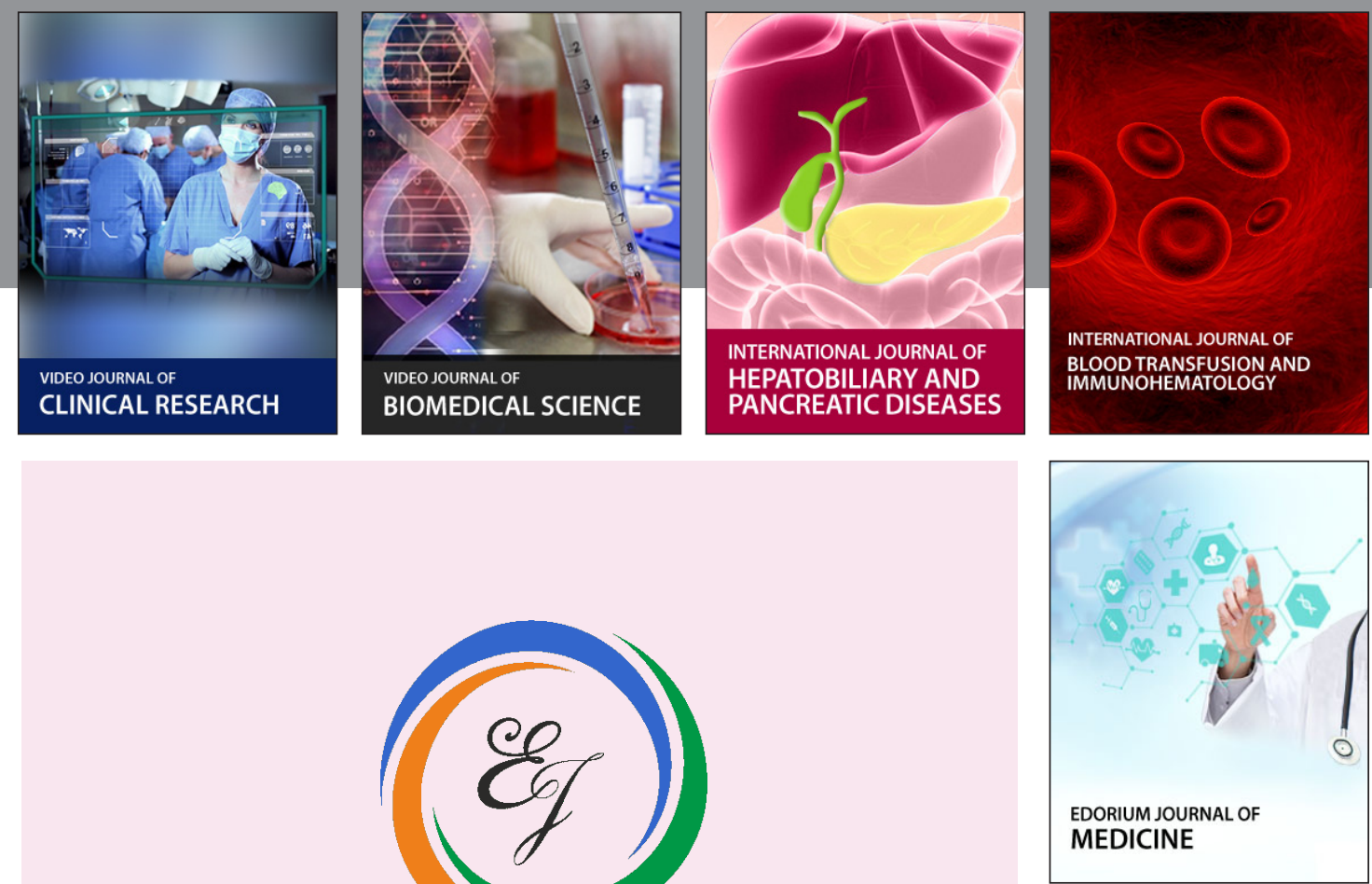

\section{Submit your manuscripts at}

www.edoriumjournals.com
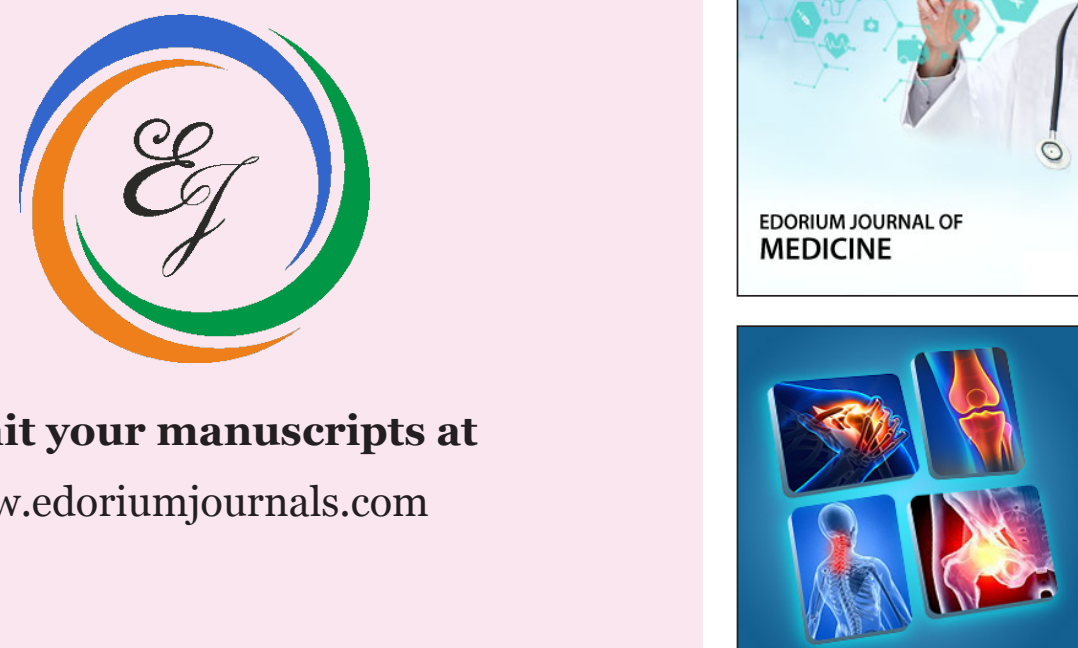

JOURNAL OF CASE REPORTS AND IMAGES IN ORTHOPEDICS AND RHEUMATOLOGY
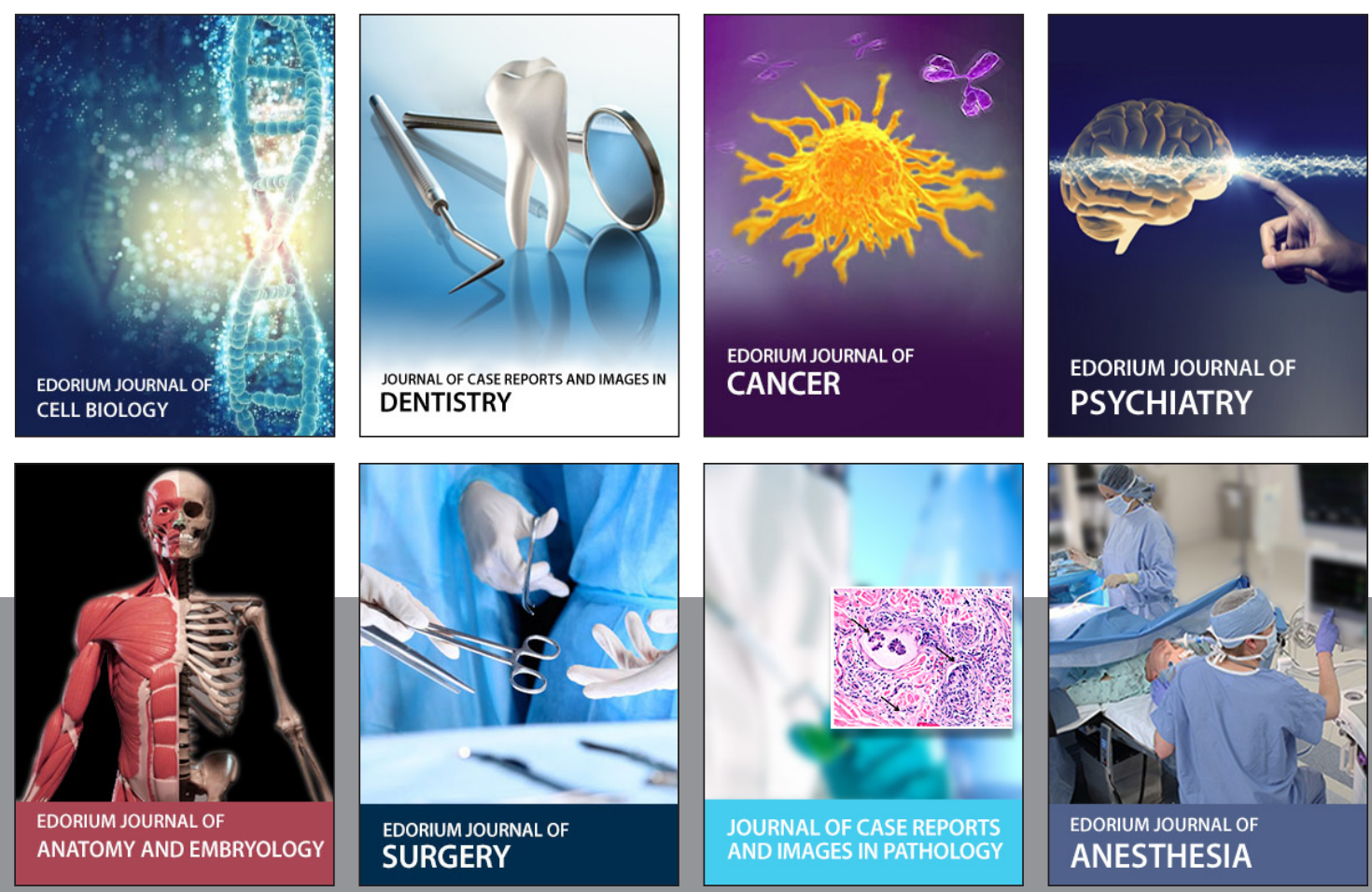